\title{
DAMPAK OBJEK WISATA CURUG CIPEUTEUY TERHADAP SOSIAL EKONOMI DAN PENDAPATAN ASLI DAERAH DI DESA BANTARAGUNG
}

\author{
Djohar Arifin, Wasman dan Fitriyani \\ Fakultas Syariah dan Ekonomi Islam \\ Institut Agama Islam Negeri Syekh Nurjati Cirebon \\ e-mail: ibnu_maksum03@yahoo.com,wasman1959@yahoo.co.id \\ danfitriyani_f@yahoo.com
}

\begin{abstract}
The existence of a tourist attraction in an area will certainly have an impact for the area and its surroundings. The impact of its management will affect the socio-economic conditions and will certainly affect the level of local revenue in the area. Departing from the problem then conducted research that aims to know the impact, and in stacking the formulation of the problems such as, how is the management system of tourist attraction cipeuteuy water fall? What is the impact of tourism management on socio-economic and local revenue? This research uses descriptive research with qualitative approach. The data collecting of this research is done by observation or observation, Interview to the management of cipeuteuy curug tourist object and the surrounding community. Based on the results of research and analysis conducted then got the conclusion that the curug tourist attraction cipeuteuy is managed with the community empowerment system that is all the management and development involves only local people. And the impact is a lot of job openings and economic improvement of the community and increase local revenue.
\end{abstract}

Keywords: Tourism Object, Socio Economic, Local Revenue.

\begin{abstract}
Abstrak
Keberadaan objek wisata di suatu daerah tentu akan memberikan dampak untuk daerah tersebut dan sekitarnya. Dampak dari pengelolaannya akan berpengaruh terhadap kondisi sosial ekonomi dan tentu akan mempengaruhi terhadap tingkat Pendapatan Asli Daerah di daerah tersebut. Berangkat dari permasalahan tersebut maka dilakukanlah penelitian yang bertujuan utntuk mengetahui dampak tersebut, dan disusunlah rumusan permasalahan diantaranya, bagaimana sistem pengelolaan objek wisata Curug Cipeuteuy? Bagaimana dampak pengelolaan objek wisata terhadap sosial ekonomi dan Pendapatan Asli Daerah? Penelitian ini meggunakan penelitian deskriptif dengan pendekatan kualitatif. Pengumpulan data penelitian ini dilakukan dengan cara pengamatan atau observasi, Wawancara kepada pihak pengelola objek wisata curug cipeuteuy dan masyarakat sekitar. Berdasarkan hasil penelitian dan analisis yang dilakukan maka didapatkan kesimpulan bahwa objek wisata curug cipeuteuy ini dikelola dengan sistem pemberdayaan masyarakat yaitu seluruh pengelolaan dan pembangunannya hanya melibatkan warga sekitar. Dan dampaknya adalah banyak membuka lapangan pekerjaan dan perbaikan ekonomi masyarakat serta meningkatkan Pendapatan Asli Daerah.
\end{abstract}

Kata Kunci: Objek Wisata, Sosial Ekonomi, Pendapatan Asli Daerah. 


\section{PENDAHULUAN}

Segala kekayaan alam yang dimiliki oleh Indonesia bisa dimanfaatkan untuk meningkatkan perekonomian dengan cara industri pariwisata. Istilah pariwisata berhubungan erat dengan pengertian perjalanan wisata, yaitu sebagai suatu perubahan tempat tinggal sementara seseorang diluar tempat tinggalnya karena suatu alasan dan bukan untuk melakukan kegiatan yang menghasilkan upah.

Dengan demikian dapat dikatakan bahwa perjalanan wisata merupakan suatu perjalanan yang dilakukan oleh seseorang atau lebih dengan tujuan antara lain untuk mendapatkan kenikmatan dan memenuhi hasrat ingin mengetahui sesuatu. Dapat diartikan juga karena kepentingan yang berhubungan dengan kegiatan olah raga untuk kesehatan, konvensi, keagamaan dan keperluan usaha lainnya. ${ }^{1}$

Pariwisata sebagai industri yang ramah lingkungan juga sering disebut sebagai industri tanpa cerobong asap jika dibandingkan dengan industri berat lainnya yang banyak menimbulkan dampak negatif terhadap lingkungan. Industri pariwisata merupakan salah satu cara yang tepat dalam meningkatkan kemajuan ekonomi masyarakat baik lokal maupun global. Pariwisata memiliki pengaruh dan manfaat yang banyak, diantaranya selain rnenghasilkan devisa Negara dan memperluas lapangan kerja, sektor pariwisata bertujuan untuk menjaga kelestarian alam dan rnengembangkan budaya lokal. $^{2}$

Pariwisata juga mampu menghasilkan pertumbuhan ekonomi, karena dapat menyediakan lapangan kerja, menstimulasi berbagai sektor produksi, serta memberikan kontribusi secara Iangsung bagi kemajuan-

\footnotetext{
${ }^{1}$ Suwantoro Gamal, Dasar-dasar Pariwisata (Yogyakarta: ANDI, 1997), 3-4.

${ }_{2}^{2}$ Annisa Ayu Anggraeni, "Analisis Dampak Ekonomi Wisata Bahari terhadap Pendapatan Masyarakat di Pulau Tidung", Jurnal Institut Teknologi Nasional 20:10 (Januari, 2013): 8.
}

kemajuan dalam usaha-usaha pembuatan dan perbaikan berbagai sarana dan prasarana yang ada di sekitar wilayah objek wisata tersebut yang bisa memberikan keuntungan dan kesenangan, baik bagi masyarakat setempat maupun wisatawan dan luar.

Selain itu, pariwisata juga merupakan salah satu sumber devisa negara yang sangat penting dan mampu memberikan sumbangan yang cukup berarti bagi pembangunan. Produk wisata konvensional mulai banyak ditinggalkan dan wisatawan beralih kepada produk wisata yang lebih menghargai lingkungan, alam dan budaya. Kepuasan wisatawan tidak lagi bersandar pada keindahan alam dan kelengkapan fasilitas wisata, melainkan juga pada keleluasaan dan intensitas interaksi dengan lingkungan dan masyarakat lokal. Berdasarkan fakta di atas, maka perlu dirumuskan bentuk pembangunan pariwisata berkelanjutan yang lebih tepat di masa mendatang. ${ }^{3}$

Salah satu objek wisata yaitu Curug Cipeuteuy yang merupakan salah satu objek wisata alam yang terdapat di desa Bantaragung kecamatan Sindangwangi kabupaten Majalengka. Objek wisata ini masuk dalam nominasi surga tersembunyi terpopuler dalam acara pesona anugerah Indonesia yang diadakan oleh Kementerian Pariwisata.

Curug Cipeuteuy ini memiliki pesona yang menarik untuk dikunjungi, karena terletak di tengah-tengah hutan pinus yang menambah asri objek wisata, serta memiliki udara sejuk. Selain memiliki panorama yang asri, curug ini juga memiliki air yang sangat jernih dan juga dingin. Penunjang bagi pengunjung yang hadir disediakan gazebo, tempat duduk, toilet dan tempat parkir. Berdasarkan data yang diperoleh dan pengelola Curug Cipeuteuy, pengunjung yang datang selalu mengalarni peningkatan dari tahun ke tahun. Objek

${ }^{3}$ Dewi Warni Susyanti, "Potensi Desa Melalui Pariwisata Pedesaan", Jurnal Ekonomi dan Bisnis 12:1 (Juni 2013): 33-36. 
wisata Curug Cipeuteuy ini banyak mendatangkan pengunjung, terutama saat akhir pekan dan hari-hari libur atau hari raya yang bisa mencapai 500 orang per hari. Adapun di hari-hari biasa, pengunjung hanya mencapai 200-250 orang saja.

Berdasakan uraian latar belakang di atas, muncul rumusan masalah, yaitu pertama, bagaimana sistem pengelolaan objek wisata curug cipeuteuy? Dan kedua, bagaimana dampak pengelolaan objek wisata terhadap sosial ekonomi dan Pendapatan Asli Daerah (PAD)?

\section{LITERATURE REVIEW}

Penelitian tentang pengaruh objek wisata terhadap sosial ekonomi dan Pendapatan Asli Daerah (PAD) memang bukanlah hal baru namun penulis mencoba membuktikan penelitian itu di tempat tinggal penulis sendiri. Berikut penelitian yang pernah dilakukan oleh Indah Tri Utami. Dengan judul penelitian "Pengaruh objek Wisata Sendang Asri Waduk Gajah Mungkur Wonogiri Terhadap Kondisi Sosial dan Ekonomi Masyarakat". Penelitian ini dilakukan karena salah satu objek wisata di jawa tengah yang terkenal adalah objek wisata Sendang Asri Waduk Gajah mungkur, yang terletak di kabupaten Wonogiri. Objek wisata Waduk Gajah Mungkur merupakan objek wisata yang dikembangkan dan satu-satunya taman rekreasi yang ada sebagai penyumbang terbesar jumlah wisatawan yang datang di kabupaten Wonogiri sampai tahun 2012. Banyaknya wisatawan yang mengunjungi objek wisata Sendang Asri Waduk Gajah mungkur sedikit banyak mempengaruhi kondisi sosial ekonomi masyarakat sekitar. Hasil penelitian ini menunjukan bahwa Objek Wisata Sendang Asri Gajah Mungkur Wonogiri berpengaruh nyata terhadap kondisi ekonomi masyarakat sekitar, khususnya dalam meningkatkan pendapatan, peluang usaha dan kerja, serta perubahan matapencaharian. ${ }^{4}$ Ni Luh Sill Antari Dengan judul penelitian "Peran Industri Pariwisata Terhadap Penerimaan Pendapatan Asli Daerah Kabupaten Gianyar". Sektor pariwisata di kabupaten Gianyar merupakan sektor yang paling diunggulkan, karena sektor pariwisata telah menjadi salah satu industri yang memberikan dampak besar terhadap peningkatan Pendapatan Asli Daerah (PAD). Sektor ini dirasakan memberikan kontribusi positif dalam memacu dan menggerakan sektor perekonomian kabupaten terhadap peningkatan pendapatan asli daerah. Sektor ini dirasakan memberikan kontribusi positif dalam memacu dan menggerakan sektor perekonomian kabupaten Gianyar. Hasil penelitian ini menunjukan bahwa kunjungan wisatawan domestik berperan terhadap penerimaan Pendapatan Asli Daerah (PAD) Kabupaten Gianyar. ${ }^{5}$

Perbedaan penelitian terdahulu dengan yang sekarang adalah objeknya yang penelitian terdahulu bertempat di Pura Tirta Empul, Kabupaten Gianyar, Kabupaten Wonogiri dan Kabupaten Wonosobo. Sedangkan penelitian sekarang dilakukan di Objek Wisata Curug Cipeuteuy yang berlokasi di Desa Bantaragung Kecamatan Sindangwangi Kabupaten Majalengka. Dan penelitian terdahulu pembahasannya terfokus pada dampak pariwisata terhadap sosial ekonomi dan sosial budaya, dan juga dampak pariwisata terhadap Pendapatan Asli Daerah. Sedangkan penelitian yang sekarang yaitu menggabungkan antara dampak pariwisata terhadap sosial ekonomi dan tingkat Pendapatan Asli Daerah (PAD).

${ }^{4}$ Indah T. Utami, "Pengaruh Objek Wisata Sendang Asri Waduk Gajah Mungkur Wonogiri terhadap Kondisi Sosial dan Ekonomi Masyarakat". (Skripsi, Fakultas Sains Komunikasi dan Pengembangan Masyarakat Institut Pertanian Bogor, 2012).

${ }^{5} \mathrm{Ni}$ Luh Sili Antari, "Peran Industri Pariwisata terhadap Penerimaan Pendapatan Asli Daerah Kabupaten Gianyar", Jurnal Perhotelan dan Pariwisata 3:1 (Agustus 2013). 


\section{METODOLOGI PENELITIAN}

Jenis penelitian yang digunakan dalam penelitian ini adalah metode penelitian deskriptif dengan pendekatan kualitatif, yang menyesuaikan latar belakang, rumusan masalah dan teori-teori yang diuraikan sebelumnya. Adapun penelitian deskriptif adalah suatu metode dalam meneliti status kelompok manusia, suatu objek, suatu situasi dan kondisi, suatu sistem pemikiran, ataupun suatu peristiwa pada masa sekarang. Hal ini bertujuan untuk membuat deskripsi, gambaran, atau lukisan secara sistematis, faktual dan akurat mengenai fakta-fakta, sifat-sifat serta hubungan antar fenomena yang diselidiki. ${ }^{6}$ Sedangkan penelitian kualitatif adalah penelitian yang bermaksud untuk memahami fenomena tentang apa yang dialami oleh subjek penelitian secara holistik, serta mendeskripsikan dalam bentuk kata-kata dan bahasa pada suatu konteks khusus yang alamiah dengan memanfaatkan berbagai metode alamiah. ${ }^{7}$

Sumber data yang digunakan adalah data primer, yaitu data yang diperoleh dari wawancara langsung dengan pihak yang terkait, seperti para pengelola objek pariwisata Curug Cipeuteuy dan masyarakat sekitar objek wisata yang merasakan keberadaan objek wisata tersebut. Dengan demikian, wawancara merupakan teknik pengumpulan data dengan cara mengadakan tanya jawab langsung dengan pihak-pihak yang terkait mengenai pengelolaan objek wisata Curug Cipeuteuy dan pihak-pihak yang merasakan dampak keberadaan objek wisata Curug Cipeuteuy yaitu masyarakat sekitar.

Kemudian data sekunder, yaitu data yang diperoleh secara tidak langsung dari pihak lain, seperti media perantara yang berbentuk catatan atau laporan historis yang telah tersusun dalam arsip (data

\footnotetext{
${ }^{6}$ Moh. Nazir, Metode Penelitian (Jakarta: Ghalia Indonesia, 2003), 54.

${ }^{7}$ Lexy J. Moleong, Metode Penelitian Kualitatf (Bandung: Remaja Rosdakarya, 2006), 6.
}

dokumentasi). Dokumentasi adalah suatu metode pengumpulan data dengan cara mengumpulkan informasi yang berasal dari dokumen-dokumen pihak pengelola yang berhubungan dengan data yang diperlukan. Data yang diperoleh dan penelitian ini diantaranya sejarah dibukanya objek wisata Curug Cipeuteuy di desa Bantaragung kecamatan Sindangwagi kabupaten Majalengka, struktur organisasi pengelola, visi dan misi, serta dokumen-dokumen pengelolaan dana hasil objek wisata.

Dilanjutkan dengan teknik pengumpulan data melalui pengamatan (observasi) secara langsung terhadap objek penelitian untuk mendukung informasi yang diperoleh. Oleh karena itu, peneliti akan melakukan pengamatan secara langsung dalam proses pengelolaan objek wisata Curug Cipeuteuy.

Kemudian teknik analisis data dalam penelitian ini bertujuan untuk mengorganisir dan mengurutkan data ke dalam pola, kategori dan satuan uraian dasar sehingga dapat ditemukan tema dan dapat dirumuskan hipotesis kerja seperti yang di sarankan oleh data. ${ }^{8}$ Analisis dalam penelitian ini akan dilakukan melalui, pertama, data reduction (reduksi data) yang diperoleh di lapangan yang jumlahnya cukup banyak, sehingga perlu dicatat secara teliti dan rinci. Dalam hal ini peneliti melakukan reduksi data dengan cara mengumpulkan, merangkum. Memilih hal-hal yang pokok kemudian menfokuskan pada data penyaluran dana hasil objek wisata.

Kedua, data display (penyajian data) bisa dilakukan dalam bentuk tabel, gambar dan bagan, serta uraian singkat yang menjelaskan hubungan antar masing-masing kategori. Kemudian ditarik conclusion drawing atau verification sebagai langkah selanjutnya untuk menarik kesimpulan. Kesimpulan awal yang dikemukakan masih bersifat sementara, dan akan berubah bila

\footnotetext{
${ }^{8}$ Sugiyono, Metode Penelitian Kuantitatif Kualitatif dan $R \& D$, Cet. Ke-20 (Bandung: Alfabeta, 2014), 103.
} 
tidak ditemukan bukti-bukti kuat yang mendukung tahap pengumpulan data berikutnya. Tetapi bila kesimpulan yang dikemukakan pada tahap awal didukung oleh bukti-bukti yang valid dan konsisten, maka kesimpulan yang dikemukakan merupakan kesimpulan yang kredibel. Dari pemaparan di atas peneliti mencoba untuk mengungkapkan bagaimana strategi pengelolaan dana hasil dari objek wisata untuk meningkatkan pendapatan daerah yang akan dipaparkan secara sederhana, yang langsung pada aspek yang diteliti. Metode analisis ini juga digunakan untuk mendapat suatu gambaran yang jelas berkaitan dengan dampak objek wisata terhadap Pendapatan Asli Daerah (PAD).

\section{KONSEP DASAR}

\section{Objek Wisata}

Kata "Objek Wisata" menurut Peraturan Pemerintah tahun 2009 tidak lagi digunakan untuk menyebut suatu daerah tujuan bagi para wisatawan, melainkan diganti dengan "Daya Tarik Wisata". Untuk memahami pengertian dan maknanya, maka akan dijelaskan lebih lanjut dalam keteranganketerangan berikut ini.

Pengertian Obyek Wisata dalam Undang-Undang Nomor 9 tahun 1990, objek dan daya tarik wisata adalah segala sesuatu yang menjadi sasaran wisata. Jadi, objek wisata adalah perwujudan dari kreasi manusia, tata hidup, seni budaya dan sejarah bangsa, serta tempat atau keadaan alam yang mempunyai daya tarik untuk dikunjungi wisatawan. ${ }^{9}$

$$
\text { Berdasarkan Undang-Undang }
$$

Nomor 10 Tahun 2009 tentang Daya Tarik Wisata bisa dijelaskan sebagai segala sesuatu yang mempunyai keunikan, keindahan, dan nilai yang berwujud keanekaragaman, kekayaan alam, budaya dan hasil buatan manusia yang menjadi sasaran atau kunjungan para wisatawan.
Objek wisata harus memiliki komponen yang bisa dijadikan alasan oleh para wisatawan untuk mengunjungi suatu objek wisata yang menjadi destinasinya. Beberapa komponen yang dimaksud, antara lain pertama, adanya some thing to see yaitu adanya sesuatu yang menjadi daya tarik khusus di daerah destinasi wisatanya, disamping interaksi wisata yang menjadi interestnya. Hal ini menjadi alasan kuat bagi para wisatawan untuk mengunjungi objek wisata tersebut, bahkan tidak hanya sekali tapi bisa berulang kali.

Kedua, adanya some thing to do yaitu selain banyak yang bisa disaksikan di suatu objek wisata harus terdapat fasilitas rekreasi yang membuat wisatawan betah untuk tinggal di objek wisata tersebut karena berwisata tentunya untuk mencari kesenangan. Oleh karena itu, objek wisata harus mampu membuat wisatawan senang sehingga tidak ingin terburu-buru untuk meninggalkan objek wisata tersebut.

Ketiga, some thing to buy yaitu ditempat wisata harus tersedia fasilitas untuk berbelanja atau membeli sesuatu yang bisa dijadikan untuk oleh-oleh, seperti souvenir, kerajinan tangan, makanan, minuman, dan lain sebagainya yang menjadi ciri khas dari daerah objek wisata tersebut. Selain nantinya wisatawan memiliki cindra mata dari objek wisata tersebut. Hal ini dimaksudkan juga agar para wisatawan menceritakan pengalamannya pada orang lain yang belum pernah mengunjungi objek wisata tersebut sehingga orang lain menjadi tertarik mendatanginya.

Dan keempat, some thing to know yaitu objek wisata harus bisa memberikan nilai edukasi atau pengetahuan bagi wisatawan yang berkunjung sehingga para wisatawan tidak hanya mendapat kesenangan semata, namun juga menambah wawasan dan pengetahuannya yang didapat dari objek wisata tersebut.

\footnotetext{
Objek Wisata.

\section{${ }^{9}$ UU No. 9 Tahun 1990 tentang}




\section{Pariwisata}

Damanik dan Weber mendefinisikan pariwisata adalah fenomena pergerakan manusia, barang dan jasa yang sangat komplek. Pariwisata terkait erat dengan organisasi, hubungan kelembagaan dan individu. Dalam arti luas pariwisata adalah kegiatan rekreasi diluar domisili untuk melepaskan diri dari pekerjaan rutin atau mencari suasana lain.

Pariwisata adalah segala sesuatu yang berhubungan dengan wisata, termasuk daya tarik wisata dan usaha-usaha yang terkait di bidang tersebut. Pariwisata merupakan suatu kegiatan yang secara langsung menyentuh dan melibatkan masyarakat, sehingga membawa berbagai dampak terhadap masyarakat setempat. Bahkan pariwisata dikatakan mempunyai efek luar biasa, yang mampu membuat masyarakat setempat mengalami perubahan dalam berbagai aspeknya. ${ }^{10}$

\section{Wisatawan}

Wisatawan merupakan bagian yang tak terpisahkan dari dunia pariwisata. Wisatawan sangat beragam, tua-muda, miskin-kaya, asing-lokal, semuanya memiliki keinginan dan juga harapan yang berbeda-beda.

Ditinjau dari arti kata, "wisatawan" yang berasal dan kata "wisata" sebenarnya tidaklah tepat sebagai pengganti kata "tourist" dalam bahasa Inggris. Kata itu berasal dan bahasa Sansekerta "wisata" yang berarti "perjalanan" yang sama atau dapat disamakan dengan kata "travel" dalam bahasa Inggris. Jadi orang melakukan perjalanan dalam pengertian ini, maka wisatawan sama artinya dengan kata "traveler", karena dalam bahasa Indonesia sudah merupakan kelaziman memakai akhiran "wan" untuk menyatakan orang

\footnotetext{
${ }^{10}$ Gede Pitana \& Gayatri Putu G., Sosiologi Pariwisata (Yogyakarta: ANDI, 2005), 109.
}

dengan profesinya, keahliannya, keadaannya jabatannya dan kedudukan seseorang. ${ }^{11}$

\section{Pengelolaan}

Arti dari kata "pengelolaan" menurut para ahli sering disamakan dengan "manajemen". Hal ini dikarenakan tujuan dari manajemen dan pengelolaan adalah sama, yaitu tercapainya tujuan organisasi lembaga. Pengelolaan dapat diartikan sebagai proses mengkoordinasikan dan mengintegrasikan semua sumber daya baik manusia maupun teknikal, untuk mencapai berbagai tujuan khusus yang ditetapkan dalam suatu organisasi. Pengertian lain tentang pengelolaan adalah suatu istilah yang berasal dari kata "kelola" mengandung arti serangkaian usaha yang bertujuan untuk menggali dan memanfaatkan segala potensi yang dimiliki secara efektif dan efisien guna mencapai tujuan tertentu yang telah direncanakan sebelumnya. Menurut beberapa para ahli menjelaskan bahwa pengelolaan, ${ }^{12}$ yaitu:

1. Menurut Soekanto, pengelolaan adalah suatu proses yang dimulai dari proses perencanaan, pengaturan, pengawasan, penggerak sampai dengan proses terwujudnya tujuan.

2. Menurut Prajudi, pengelolaan ialah pengendalian dan pemanfaatan semua faktor sumber daya yang menurut suatu perencana diperlukan untuk penyelesaian suatu tujuan kerja tertentu.

3. Menurut Balderton, pengelolaan yaitu menggerakkan, mengorganisasikan dan mengarahkan usaha manusia untuk memanfaatkan secara efektif material dan fasilitas untuk mencapai suatu tujuan.

4. Menurut Moekijat, pengelolaan merupakan rangkaian kegiatan yang

\footnotetext{
${ }^{11}$ Koko Irawan, "Potensi Objek Wisata Air Terjun Serdang sebagai Daya Tarik Wisata di Kabupaten Labuhan Batu Utara". (Makalah, Program Pendidikan Non Gelar Pariwisata Universitas Sumatera Utara, 2010), 12.

${ }^{12}$ Rahardjo Adisasmita, Pengelolaan Pendapatan dan Anggaran Daerah (Yogyakarta: Graha Ilmu, 2011), 19.
} 
meliputi perencanaan, pengorganisasian, petunjuk, pelaksanaan, pengendalian dan pengawasan.

5. Menurut Hamalik, pengelolaan adalah suatu proses untuk menggerakkan, mengorganisasikan dan mengerahkan usaha manusia untuk mencapai tujuannya.

\section{Pemberdayaan Masyarakat}

Empowerment yang diterjemahkan dalam bahasa Indonesia berarti pemberdayaan, yaitu sebuah konsep yang lahir sebagai bagian dari perkembangan alam pikiran masyarakat dan kebudayaan barat utamanya Eropa. Untuk memahami konsep empowerment secara tepat dan jernih memerlukan upaya pemahaman latar belakang kontekstual yang melahirkannya.

Secara konseptual pemberdayaan berasal dari kata power (kekuasaan atau keberdayaaan), karena ide utama pemberdayaan bersentuhan dengan konsep mengenai kekuasaan. Kekuasaan seringkali dikaitkan dengan kemampuan kita untuk membuat orang lain melakukan apa yang kita inginkan, terlepas dari keinginan dan niat mereka. Ilmu sosial tradisional menekankan bahwa kekuasaan berkaitan dengan pengaruh dan kontrol.

Pengertian ini mengasumsikan bahwa kekuasaan sebagai suatu yang tidak berubah atau tidak dapat dirubah. Kekuasaan senantiasa tercipta dan hadir dalam konteks relasi sosial antar manusia. Karena itu kekuasaan dan hubungan kekuasaan dapat berubah. Dengan pemahaman kekuasaan seperti itu, pemberdayaan sebagai sebuah proses perubahan kemudian memiliki konsep yang bermakna. Inilah Beberapa Definisi Pemberdayaan Masyarakat Menurut Para Ahli.

Pemberdayaan menurut Suhendra adalah "suatu kegiatan yang berkesinambungan, dinamis, secara sinergis mendorong keterlibatan semua potensi yang ada secara evolutif dengan keterlibatan semua potensi". ${ }^{13}$ Sedangkan menurut Widjaja pemberdayaan masyarakat adalah upaya meningkatkan kemampuan dan potensi yang dimiliki masyarakat, sehingga masyarakat dapat mewujudkan jati diri, harkat dan martabatnya secara maksimal untuk bertahan dan mengembangkan diri secara mandiri baik di bidang ekonomi, sosial, agama dan budaya. ${ }^{14}$

\section{Sosial Ekonomi}

Berdasarkan pengertian sosial dan pengertian ekonomi yang telah dibahas sebelumnya, dapat di tarik kesimpulan bahwa sosial ekonomi adalah segala sesuatu yang berkaitan dengan pemenuhan kebutuhan masyarakat antara lain sandang, pangan, papan, pendidikan, kesehatan dan sebagainya. Pemenuhan kebutuhan tersebut berkaitan dengan penghasilan. Hal ini disesuaikan dengan penelitian yang dilakukan. Untuk melihat kedudukan sosial ekonomi, perlu kiranya melihat pekerjaan, penghasilan dan pendidikan suatu masyarakat. Berdasarkan hal ini, masyarakat dapat digolongkan ke dalam kedudukan sosial ekonomi rendah, sedang ataupun tinggi berdasarkan pendapatannya.

Dengan demikian, pendapatan dapat didefinisikan sebagai upah, gaji, keuntungan sewa dan setiap aliran pendapatan yang diterima. Namun, cara lain untuk melihat generasi sumber penghasilan (pendapatan) yaitu dalam bentuk kompensasi pekerjaan, jaminan sosial, uang pensiun, kepentingan atau dividen, royalti, piutang, tunjangan atau tunjangan lain dari pemerintah, masyarakat, atau bantuan keuangan keluarga.

Pendapatan dapat dilihat dalam dua istilah, relatif dan mutlak. Pendapatan mutlak adalah hubungan yang seiring dengan kenaikan pendapatan dan keperluan konsumsi, tetapi tidak pada tingkat yang

\footnotetext{
${ }^{13}$ Suhendra, Peranan Birokrasi dalam Pemberdayaan Masyarakat (Bandung: Alfabeta. 2006), 74-75.

${ }^{14}$ HAW. Widjaja, Otonomi Desa Merupakan Otonomi Asli Bulat dan Utuh (Jakarta: PT. Raja Grafindo Persada, 2003), 169.
} 
sama. Pendapatan relatif menentukan seorang atau tabungan keluarga dan konsumsi berdasarkan pendapatan keluarga dalam kaitannya dengan orang lain.

Keluarga dengan pendapatan yang lebih tinggi dan mengeluarkan uang dapat mengumpulkan kekayaan dan fokus pada pemenuhan kebutuhan mendesak, sambil dapat mengkonsumsi dan menikmati kemewahan dan krisis cuaca.

Tingkat pendidikan sesuai dengan SES karena merupakan fenomena "cross cutting" untuk semua individu. Pencapaian pendidikan individu dianggap sebagai cadangan untuk semua prestasi dalam hidup, yang tercermin melalui nilai-nilai atau derajatnya. Akibatnya, pendidikan memainkan sebuah peran dalam pendapatan.

Pendidikan memberikan dorongan untuk meningkatkan penghasilan. Sebagaimana disampaikan pada grafik, derajat tertinggi, gelar profesional dan doktor, membuat pendapatan mingguan tertinggi sementara mereka tanpa ijazah sekolah tinggi tercukupi secara finansial. Tingkat pendidikan yang lebih tinggi berhubungan dengan hasil ekonomi dan psikologis yang lebih baik.

Pendidikan memäinkan peranan penting dalam mengasah keterampilan seorang individu yang membuat dia sebagai orang yang siap untuk mencari dan memperoleh pekerjaan, serta kualifikasi khusus yang mengelompokkan orang dengan SES tertinggi dan SES terendah. Annette Lareau berbicara pada gagasan budidaya terpadu, di mana orang tua kelas menengah mengambil peran aktif dalam pendidikan dan pengembangan anak-anak mereka dengan menggunakan kendali mengorganisir kegiatan dan mendorong rasa hak melalui diskusi.

\section{Pendapatan Asli Daerah (PAD)}

Pendapatan ash daerah adalah penerimaan yang diperoleh dan sektor pajak daerah, retribusi daerah hasil perusahaan milik daerah, hasil pengelolaan kekayaan daerah yang dipisahkan dan lain-lain pendapatan yang sah. ${ }^{15}$

Pendapatan Asli Daerah (PAD) merupakan semua penerimaan daerah yang berasal dan sumber ekonomi ash daerah, pendapatan ash daerah dipisahkan menjadi empat jenis pendapatan, yaitu pajak daerah, retribusi daerah, hasil perusahaan milik daerah dan hasil pengelolaan kekayaan milk daerah yang dipisahkan, lain-lain pendapatan ash daerah yang sah. ${ }^{16}$

Sedangkan menurut Undang-Undang No. 34 tahun 2004 tentang penimbangan keuangan Negara antara pemenintah pusat dan pemenintah daerah membagi PAD menjadi tiga bagian, ${ }^{17}$ yaitu:

1. Pajak asli daerah bersumber dari:

a. Pajak daerah

b. Retribusi daerah

c. Hasil pengelolaan kekayaan daerah yang dipisahkan

d. Lain-lain PAD yang sah

2. Dana Perimbangan

Dana Perimbangan yaitu dana yang bersumber dan pendapatan APBN yang dialokasikan kepala daerah untuk mendanai kebutuhan daerah dalam rangka pelaksanaan desentralisasi.

3. Lain-lain Pendapatan Daerah yang Sah.

Berdasarkan beberapa pendapat diatas dapat dismpulkan bahwa PAD merupakan pendapatan yang diperoleh dan sumber-sumber pendapatan daerah dan dikelola sendiri oleh pemerintah daerah. Pendapatan daerah juga merupakan pendapatan yang diperoleh oleh pemerintah daerah dan digali dan potensi pendapatan yang ada di daerah. Dengan kata lain PAD merupakan pendapatan yang diterima oleh pemerintah daerah atas segala sumbersumber atau potensi yang ada pada daerah

\footnotetext{
${ }^{15}$ Mardiasmo, Otonomi dan Manajemen Keuangan Daerah (Yogyakarta: ANDI, 2004), 132.

${ }^{16}$ Abdul Halim, "Anggaran Daerah dan Fiscal Stress (Sebuah Studi Kasus pada Anggaran Daerah Provinsi di Indonesia)", Jurnal Ekonomi dan Bisnis Indonesia 14:1 (Juni 2014), 4.

${ }^{17} \mathrm{UU}$ No. 34 Tahun 2004 tentang Perimbangan Keuangan Negara.
} 
yang harus diolah oleh pemerintah daerah di dalam memperoleh pendapatan daerah.

Kemampuan daerah dalam melaksanakan otonominya sangat ditentukan atau tergantung dan sumbersumber pendapatan ash daerah (PAD). Pemenintah daerah dituntut untuk dapat menghidupi dirinya sendiri dengan mengadakan pengelolaan terhadap potensi yang dimiliki, untuk itu usaha untuk mendapatkan sumber dana yang tepat merupakan suatu keharusan. Terobosanterobosan baru dalam memperoleh dana untuk membiayai pengeluaran pemerintah daerah hams dilakukan, salah satunya adalah sektor pariwisata.

\section{PEMBASAHASAN DAN DISKUSI}

Kawasan objek wisata Curug Cipeuteuy berbentuk pemberdayaan masyarakat, yang berarti masyarakat sekitar bisa mengambil manfaat dari adanya objek wisata ini. Objek wisata curug cipeuteuy dalam pembangunan dan pengelolaannya sama sekali tidak melibatkan pihak luar, seluruhnya memakai jasa warga sekitar. Seperti yang merancang denah lokasi, bahkan pengerjaannya dilakukan oleh warga sekitar yang memiliki keahlian dalam dalam bidang konstruksi.

Objek wisata Curug Cipeuteuy dibangun dengan sistem buttom up atau dibangun bertahap dari dasar lalu terus dilakukan pengembangan untuk menambah daya tariknya. Seperti pada awalnya curug cipeuteuy hanya membuat satu kolam untuk membendung air curug, kemudian terus dikembangkan di buat kolam-kolam selanjutnya, lalu dibuat jembatan cinta yang kini menjadi icon objek wisata Curug Cipeuteuy. ${ }^{18}$

Di dalam objek wisata ini juga disediakan kavling-kavling yang disewakan untuk masyarakat yang akan berjualan di dalam lokasi objek wisata. Kavling ini memiliki luas yang sama rata yaitu memiliki lebar 2 meter dan panjang 3 meter dengan

\footnotetext{
${ }^{18}$ Wawancara Marta Atmadja ketua pengelola objek wisata Curug Cipeuteuy.
}

vasilitas yang sama yaitu setengah untuk kantin lesehan dan setengah untuk kantin memakai kursi dan di tengan untuk barangbarang yang dijual. Kavling ini disewakan sebesar Rp.2.000.000 untuk setiap tahunnya. Bagi masyarakat yang ingin berjualan tentunya harus melalui izin kepada pengelola, lalu dibuatkan kontrak oleh pengelola.

Adanya pengelolaan, pemeliharaan dan pengembangan yang terus-menerus membuat kondisi objek wisata Curug Cipeuteuy memiliki daya tarik yang semakin bertambah. Hal ini dapat membawa dampak baik bagi jumlah wisatawan yang selalu bertambah, dan tentunya mempengaruhi hasil retribusi.

\section{Dampak terhadap Sosial Ekonomi}

Di tahun 2008 adalah masa dimana belum dibukanya objek wisata Curug Cipeuteuy yang terletak di desa Bantaragung kecamatan Sindangwangi kabupaten Majalengka, pada masa ini keadaan sosial ekonomi masyarakat cukup rendah. Banyak pemuda yang menganggur, ataupun warga dengan pekerjaan serabutan atau hanya buruh tani, penghasilan mereka tidak menentu. Masyarakat ini juga belum begitu sadar akan pendidikan karena terhambat oleh biaya pendidikan yang dianggap cukup mahal bila dihitung dengan peghasilan mereka. Sebelum adanya objek wisata ini anak-anak disekitar objek wisata rata-rata menyelesaikan pendidikan hanya sampai tingkat menengah pertama di sekolah negeri.

Pada tahun 2009 dimana awal dibukanya proyek pembangnuan objek wisata Curug Cipeuteuy pada masa ini dimulai perlahan-lahan menyediakan lapangan pekerjaan untuk warga sekitar, karena objek wisata ini bersifat pemberdayaan masyarakat maka pembangunan dan pengembangannya sebisa mungkin hanya memanfaatkan sumberdaya alam dan sumber daya manusia dari daerah sekitar saja. 
Mulanya masyarakat mendapatkan lapangan pekerjaan di bidang konstruksi untuk melaksanan rencana pembangunan dan penataan denah lokasi objek wisata. Setelah objek wisata siap untuk dibuka lalu tersedianya lapangan pekerjaan untuk para pengelola tenaga kerja yang mampu diserap oleh objek wisata ini, misalnya penjaga parkir, penjaga karcis, pemelihara kebersihan dan keindahan, penjagaan keamanan dan lain sebagainya. ${ }^{19}$

Masyarakat bisa membuka usaha berjualan di dalam lokasi objek wisata dengan menempati kavling-kavling yang telah disediakan oleh pengelola untuk disewakan kepada masyarakat. Selain berjualan makanan, minuman dan pakaian, warga juga bisa menyediakan sewa pakian renang tikar ataupun pelampung. Para pedagang ini mengaku bisa mendapatkan penghasilan sekitar Rp.500.000Rp.1.000.000 setiap harinya di hari-hari biasa, sementara saat hari libur dan hari-hari besar lainnya para pedagang mengaku bisa mendapatkan keuntungan dari Rp.1.000.000 - Rp.1.500.000. ${ }^{20}$

Warga sekitar yang daerahnya dilalui oleh rute menuju objek wisata Curug Cipeuteuy lalu melihat pelung dengan banyaknya wisatawan yang berkunjung. Terkadang mereka menemui wisatawan yang mengalami permasalahan dengan kendaraanya, lalu mereka berinisiatif untuk membuat bengkel, berjualan bensin eceran, membuka warung, membuka konter dan sebagainya. $^{21}$

Setelah dibuka objek wisata Curug Cipeuteuy terlihat perubahan perekonomian masyarakat di sekitarnya. Hal ini terlihat dari bentuk rumah dan kendaraan yang digunakan, serta pakaian yang dikenakan. Sebelum adanya objek wisata ini, masyarakat rata-rata hanya memiliki satu

\footnotetext{
${ }^{19}$ wawancara dengan bapak yanto pekerja konstruksi di objek wisata Curug Cipeuteuy.

${ }^{20}$ wawancara dengan ibu opi pedagang di dalam objek wisata Curug Cipeuteuy.

${ }^{21}$ Wawancara dengan ibu Kanah pemilik warung makan objek wisata Curug Cipeuteuy.
}

kendaraan roda dua di setiap rumahnya. Namun, setelah adanya objek wisata Curug Cipeuteuy ini, masyarakat rata-rata memiliki dua kendaran di setiap rumahnya.

Adapun dari tingkat pendidikan bisa dijadikan rujukan untuk memperhitungkan tingkat kemapanan hidup masyarakat sekitar. Setelah dibukanya objek wisata Curug Cipeuteuy, anak-anak di daerah tersebut banyak yang melanjutkan sekolah ke tingkat menengah atas maupun kejuruan, bahkan sampai ke perguruan tinggi baik negeri maupun swasta. Hal ini mengindikasikan bahwa keberadaan objek wisata Curug Cipeuteuy memberikan dampak positif bagi pendanaan warga sekitar.

\section{Dampak terhadap Pendapatan Asli Daerah}

Sebelum adanya objek wisata, desa Bantaragung hanya memiliki pendapatan yang berasal dari bagi hasil pajak daerah dan retribusi daerah Kabupaten Majalengka, bagian dana perimbangan pusat dan daerah yang diterima oleh Kabupaten Majalengka, alokasi anggaran dana desa dari APBN, serta bantuan keuangan dari APBD Provinsi dan APBD Kabupaten Majalengka.

Namun setelah adanya objek wisata Curug Cipeuteuy, sedikit banyak pendapatan desa mengalami peningkatan secara perlahan-lahan. Selain berpengaruh pada pendapatan desa, objek wisata Curug Cipeuteuy juga sebagai penyumbang terbesar saat ada acara-acara desa, seperti PORPAB, perbaikan jalan, perayaan 17 Agustus dan lain sebagainya.

\section{KESIMPULAN}

Dari pembahasan di atas, dapat diambil 2 (dua) kesimpulan, yaitu pertama, bentuk objek wisata Curug Cipeuteuy berupa objek wisata alam, yang berlokasi di desa Bantaragung kecamatan Sindangwangi kabupaten Majalengka. Objek wisata ini memiliki fasilitas utama yaitu curug, bumi perkemahan, arboretum dan pengamatan satwa, jalur hiking dan juga memiliki 
fasilitas penunjang berupa loket tiket, area parkir, warung, toilet, mushola, tempat beristirahat, tempat sampah dan papan penunjuk arah. Sistem pengelolaan objek wisata ini menggunakan sistem memberdayakan potensi yang ada di desa Bantaragung, dan dibangun dengan sistem bertahap dengan pengerjaan dan pengelolaan dilakukan oleh masyarakat sekitar.

Dan kedua, dampak sosial meliputi penyediaan lapangan pekerjaan, perbaikan sumber daya alam, dan juga berdampak pada PAD di desa Bantaragung yang mengalami peningkatan.

\section{DAFTAR PUSTAKA}

Adisasmita, Rahardjo. Pengelolaan Pendapatan dan Anggaran Daerah. Yogyakarta: Graha Ilmu, 2011.

Anggraeni, Annisa Ayu. "Analisis Dampak Ekonomi Wisata Bahari terhadap Pendapatan Masyarakat di Pulau Tidung”. Jurnal Institut Teknologi Nasional 20:10 (Januari, 2013).

Antari, Ni Luh Sili. "Peran Industri Pariwisata terhadap Penerimaan Pendapatan Asli Daerah Kabupaten Gianyar". Jurnal Perhotelan dan Pariwisata 3:1 (Agustus 2013).

Gamal, Suwantoro. Dasar-dasar Pariwisata. Yogyakarta: ANDI, 1997.

Halim, Abdul. "Anggaran Daerah dan Fiscal Stress (Sebuah Studi Kasus pada Anggaran Daerah Provinsi di Indonesia)". Jurnal Ekonomi dan Bisnis Indonesia 14:1 (Juni 2014).

Irawan, Koko. "Potensi Objek Wisata Air Terjun Serdang sebagai Daya Tarik Wisata di Kabupaten Labuhan Batu Utara". Makalah, Program Pendidikan Non Gelar Pariwisata Universitas Sumatera Utara, 2010.

Mardiasmo. Otonomi dan Manajemen Keuangan Daerah. Yogyakarta: ANDI, 2004.
Moleong, Lexy J. Metode Penelitian Kualitatf. Bandung: Remaja Rosdakarya, 2006.

Nazir, Moh. Metode Penelitian. Jakarta: Ghalia Indonesia, 2003.

Pitana, Gede Pitana \& Gayatri Putu G. Sosiologi Pariwisata. Yogyakarta: ANDI, 2005.

Sugiyono. Metode Penelitian Kuantitatif Kualitatif dan $R \& D$, Cet. Ke-20. Bandung: Alfabeta, 2014.

Suhendra. Peranan Birokrasi dalam Pemberdayaan Masyarakat. Bandung: Alfabeta. 2006.

Susyanti, Dewi Warni. "Potensi Desa Melalui Pariwisata Pedesaan". Jurnal Ekonomi dan Bisnis 12:1 (Juni 2013).

Utami, Indah T. "Pengaruh Objek Wisata Sendang Asri Waduk Gajah Mungkur Wonogiri terhadap Kondisi Sosial dan Ekonomi Masyarakat". Skripsi, Fakultas Sains Komunikasi dan Pengembangan Masyarakat Institut Pertanian Bogor, 2012.

Undang-Undang Nomor 34 Tahun 2004 tentang Perimbangan Keuangan Negara.

Undang-Undang Nomor 9 Tahun 1990 tentang Objek Wisata. 